\title{
Synthesis of 1,5-Diaryl-1,4-pentadien-3-one Amidinohydrazone Hydrochloride Under Ultrasound Irradiation
}

\author{
CHAO DU AND JI-TAI LI ${ }^{*}$ \\ Key Laboratory of Analytical Science and Technology of Hebei Province \\ Key Laboratory of Medical Chemistry and Molecular Diagnosis \\ Ministry of Education, College of Chemistry and Environmental Science \\ Hebei University, Baoding 071002, P. R. China \\ lijitai@hbu.cn
}

Received 26 July 2011; Accepted 5 September 2011

\begin{abstract}
Synthesis of 1,5-diaryl-1,4-pentadien-3-one amidinohydrazone hydrochloride via the condensation of 1,5-diaryl-1,4-pentadien-3-one and aminoguanidine hydrochloride catalyzed by hydrochloric acid was carried out in $80-94 \%$ yield at $35-37^{\circ} \mathrm{C}$ within $1.5 \mathrm{~h}$ under ultrasound irradiation. Compared to the classical method, the advantages of this method are milder conditions, shorter reaction time and higher yield.
\end{abstract}

Keywords: 1,5-Diaryl-1,4-pentadien-3-one amidinohydrazone hydrochloride, Synthesis, Ultrasound irradiation, Condensation.

\section{Introduction}

Amidinohydrazone derivatives play important roles in medicinal chemistry due to their fragments are featured in many pharmacologically and biologically active compounds ${ }^{1-5}$. Especially, 1,5-diaryl-1,4-pentadien-3-one amidinohydrazone hydrochlorides take a famous effect in the amidinohydrazone derivatives. These compounds are useful as anti-tubercular and anti-malarial agents in warm-blooded animals ${ }^{6,7}$ and are also useful as insecticidal agents $^{8,9}$.

Generally, 1,5-diaryl-1,4-pentadien-3-one amidinohydrazone salt are synthesized from 1,5-diaryl-1,4-pentadien-3-one and amidinohydrazone salt. Tomcufcik et al. reported that the synthesis of four 1,5-diaryl-1,4-pentadien-3-one amidinohydrazone hydrochloride was carried out in 40-70\% yield under refluxing EtOH via the condensation of bischalcone with aminoguanidine hydrochloride catalyzed by hydrochloric acid, but a long reaction time (4-16 h) was required ${ }^{8}$.

Ultrasound has increasingly been considered as a clean and useful protocol in organic synthesis in recent years. Compared with traditional methods, the procedure is more convenient. A large number of organic reactions can be carried out in higher yield, shorter 
reaction time, and milder conditions under ultrasound irradiation ${ }^{10,11}$. It appears that the condensation of bischalcone with aminoguanidine hydrochloride by using ultrasound has not been reported earlier. Herein, we wish to report an efficient improved synthesis of 1,5-diaryl-1,4-pentadien-3-one amidinohydrazone hydrochloride via condensation of 1,5-diaryl-1,4-pentadien-3-one with aminoguanidine hydrochloride catalyzed by hydrochloric acid in ethanol under ultrasound irradiation (Scheme 1).

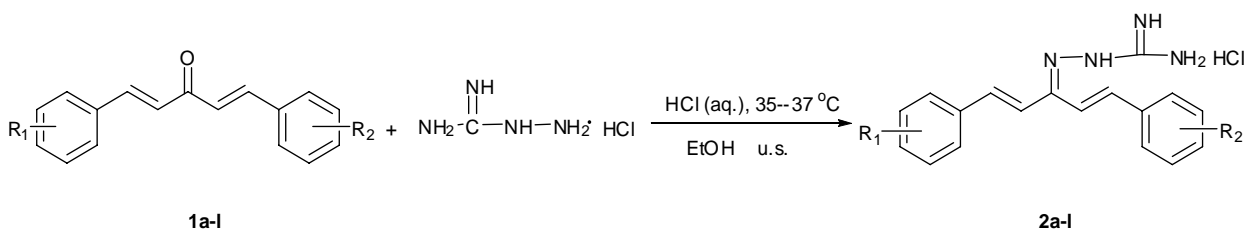

Scheme 1. Synthesis of bischalcone aminoguanidine hydrochloride.

\section{Experimental}

\section{1,5-Diaryl-1,4-pentadien-3-ones were prepared according to the literature ${ }^{14}$}

Melting points were uncorrected. MS were determined on Agilent Technologies 6310 Lon Trap LC/MS or Bruker apex ultra 7.0 T spectrometer. The ${ }^{1} \mathrm{H}$ NMR $(600 \mathrm{MHz})$ and ${ }^{13} \mathrm{C}$ NMR (150 MHz) spectra were recorded on a Bruker AVANCE III 600 spectrometer using TMS as internal standard and DMSO- $\mathrm{d}_{6}$ as solvent. Sonication was performed in Shanghai Branson BUG 25-06 ultrasonic cleaner (with a frequency of $25 \mathrm{kHz}$ and a nominal power $250 \mathrm{~W}$ ). The total acoustic power injected into the sample solution was found to be $0.63 \mathrm{~W}$ by calorimetry ${ }^{15}$.

General procedure for the synthesis of 1,5-diaryl-1,4-pentadien-3-one amidinohydrazone hydrochloride

1,5-Diaryl-1,4-pentadiene-3-one(1, $1 \mathrm{mmol})$, aminoguanidine hydrochloride (121 mg, $1.1 \mathrm{mmol})$, hydrochloric acid $(36.5 \%, 0.05 \mathrm{~mL})$ and ethanol $(10 \mathrm{~mL})$ were added into a $25 \mathrm{~mL}$ round bottomed flask. The reaction flask was located the cleaner bath, where the surface of reactants was slightly lower than the level of the water. In the water bath of the ultrasonic cleaner, the reaction mixture was irradiated at $35-37^{\circ} \mathrm{C}$ for the period of time as indicated in Table 2. The reaction was monitored by TLC (silica, $\mathrm{CH}_{3} \mathrm{OH}: \mathrm{CH}_{2} \mathrm{Cl}_{2}=$ $1: 4, \mathrm{~V} / \mathrm{V})$, the reaction temperature was controlled by removal or addition of water from ultrasonic bath. After the completion of the reaction, the solvent was evaporated under reduced pressure, and the residue was dissolved in $\mathrm{CH}_{2} \mathrm{Cl}_{2}(10 \mathrm{~mL})$ and washed with water. The organic layer was dried over anhydrous $\mathrm{Na}_{2} \mathrm{SO}_{4}$ overnight and filtered. The solvent was removed by evaporation under reduced pressure to give the crude products, which were further purified by column chromatography on silica (200-300 mesh) eluted with petroleum ether (b.p. $60-90^{\circ} \mathrm{C}$ ) or a mixture of $\mathrm{CH}_{3} \mathrm{OH}$ and $\mathrm{CH}_{2} \mathrm{Cl}_{2}$ (1:30). The authenticity of the products (2a-e) was established by comparing their melting points with data reported in literatures ${ }^{8}$, the others (2f-l) were established by their ${ }^{1} \mathrm{H}$ NMR, ${ }^{13} \mathrm{C}$ NMR and MS.

\section{2a: 1,5-Diphenyl-1,4-pentadien-3-one amidinohydrazone hydrochloride}

${ }^{1} \mathrm{H}$ NMR $\delta_{\mathrm{H}}: 7.25$ (d, $\left.J=16 \mathrm{~Hz}, 1 \mathrm{H}, \mathrm{CH}\right), 7.34-7.43(\mathrm{~m}, 6 \mathrm{H}, \mathrm{Ph}-\mathrm{H}), 7.45$ (d, $J=16 \mathrm{~Hz}, 1 \mathrm{H}$, $\mathrm{CH}), 7.54$ (d, $J=16 \mathrm{~Hz}, 1 \mathrm{H}, \mathrm{CH}), 7.62(\mathrm{~d}, J=16 \mathrm{~Hz}, 1 \mathrm{H}, \mathrm{CH}), 7.70$ (d, $J=7.4 \mathrm{~Hz}, 2 \mathrm{H}$, $\mathrm{NH}_{2}$ ), 7.90-7.92 (m, 4H, Ph-H), 7.96 (brs, $\left.1 \mathrm{H}, \mathrm{NH}\right), 12.11$ (s, $\left.1 \mathrm{H}, \mathrm{NH}\right) ;{ }^{13} \mathrm{C}$ NMR $\delta_{\mathrm{C}}: 156.4$, 149.1, 139.3, 136.8, 135.4, 130.0, 129.3, 129.2, 129.1, 128.7, 127.8, 122.9, 119.2; HRMS $\mathrm{m} / z$ (ESI): calcd for $\mathrm{C}_{18} \mathrm{H}_{19} \mathrm{~N}_{4}[\mathrm{M}+\mathrm{H}]^{+}$291.1604, found 291.1605. 
2f: 1-(4-Methylphenyl)-5-phenyl-1,4-pentadien-3-one amidinohydrazone hydrochloride ${ }^{1} \mathrm{H}$ NMR $\delta_{\mathrm{H}}: 2.33$ (s, 3H, $\mathrm{CH}_{3}$ ), 7.12 (d, $\left.J=16 \mathrm{~Hz}, 1 \mathrm{H}, \mathrm{CH}\right), 7.16-7.26$ (m, 5H, Ph-H), 7.28 (d, $J=16 \mathrm{~Hz}, 1 \mathrm{H}, \mathrm{CH}), 7.32$ (d, $J=16 \mathrm{~Hz}, 1 \mathrm{H}, \mathrm{CH}), 7.37$ (d, $J=16 \mathrm{~Hz}, 1 \mathrm{H}, \mathrm{CH}), 7.40$ (d, $J$ $\left.=8 \mathrm{~Hz}, 2 \mathrm{H}, \mathrm{NH}_{2}\right), 7.50-7.62(\mathrm{~m}, 4 \mathrm{H}, \mathrm{Ph}-\mathrm{H}), 7.65$ (brs, $\left.1 \mathrm{H}, \mathrm{NH}\right), 11.62(\mathrm{~s}, 1 \mathrm{H}, \mathrm{NH}) .{ }^{13} \mathrm{C}$ NMR $\delta_{\mathrm{C}}$ : 153.4, 147.1, 139.2, 135.8, 129.8, 129.7, 129.1, 129.0, 127.6, 127.5, 127.1, 22.1; HRMS $m / z$ (ESI): calcd for $\mathrm{C}_{19} \mathrm{H}_{21} \mathrm{~N}_{4}[\mathrm{M}+\mathrm{H}]^{+}$305.1761, found 305.1764.

2g:1-(4-Methoxylphenyl)-5-phenyl-1,4-pentadien-3-one amidinohydrazone hydrochloride

${ }^{1} \mathrm{H}$ NMR $\delta_{\mathrm{H}}: 3.80$ (s, 3H, CH ), 7.24 (d, $\left.J=16 \mathrm{~Hz}, 1 \mathrm{H}, \mathrm{CH}\right), 7.31-7.44$ (m, 6H, Ph-H), 7.45 (d, $J=16 \mathrm{~Hz}, 1 \mathrm{H}, \mathrm{CH}), 7.52$ (d, $J=8.4 \mathrm{~Hz}, 1 \mathrm{H}, \mathrm{CH}), 7.63$ (d, $J=8.4 \mathrm{~Hz}, 1 \mathrm{H}, \mathrm{CH}), 7.68$ (d, $\left.J=7.5 \mathrm{~Hz}, 2 \mathrm{H}, \mathrm{NH}_{2}\right), 7.78-7.84(\mathrm{~m}, 3 \mathrm{H}, \mathrm{Ph}-\mathrm{H}), 7.87$ (brs, $\left.1 \mathrm{H}, \mathrm{NH}\right) .{ }^{13} \mathrm{C}$ NMR $\delta_{\mathrm{C}}$ : 160.9 , 160.2, 156.5, 136.8, 130.2, 129.8, 129.1, 129.0, 128.5, 127.7, 123.1, 114.7, 55.8; HRMS m/z (ESI): calcd for $\mathrm{C}_{19} \mathrm{H}_{21} \mathrm{~N}_{4} \mathrm{O}[\mathrm{M}+\mathrm{H}]^{+} 321.1710$, found 321.1712 .

2h: 1,5-Bis(4-methoxylphenyl)-1,4-pentadien-3-one amidinohydrazone hydrochloride ${ }^{1} \mathrm{H}$ NMR $\delta_{\mathrm{H}}: 3.81$ (s, 6H, CH $)$, 6.96-7.01 (m, 4H, Ph-H), 7.08 (d, $\left.J=16 \mathrm{~Hz}, 1 \mathrm{H}, \mathrm{CH}\right), 7.38$ (d, $J=16 \mathrm{~Hz}, 1 \mathrm{H}, \mathrm{CH}), 7.42$ (d, $J=16 \mathrm{~Hz}, 1 \mathrm{H}, \mathrm{CH}), 7.46$ (d, $J=16 \mathrm{~Hz}, 1 \mathrm{H}, \mathrm{CH}), 7.63$ (d, $J$ $\left.=8.6 \mathrm{~Hz}, 2 \mathrm{H}, \mathrm{NH}_{2}\right), 7.70$ (brs, $\left.1 \mathrm{H}, \mathrm{NH}\right), 7.76-7.86(\mathrm{~m}, 4 \mathrm{H}, \mathrm{Ph}-\mathrm{H}), 11.83(\mathrm{~s}, 1 \mathrm{H}, \mathrm{NH}) ;{ }^{13} \mathrm{C}$ NMR $\delta_{\mathrm{C}}$ : 160.9, 160.2, 156.0, 150.7, 139.2, 134.9, 130.2, 129.5, 129.2, 128.9, 120.6, 116.9, 114.6, 55.7, 55.8; HRMS $m / z$ (ESI): calcd for $\mathrm{C}_{20} \mathrm{H}_{23} \mathrm{~N}_{4} \mathrm{O}_{2}[\mathrm{M}+\mathrm{H}]^{+} 351.1816$, found 351.1818.

2i: 1,5-Bis(3,4-dioxanemethylphenyl)-1,4-pentadien-3-one amidinohydrazone hydrochloride

${ }^{1} \mathrm{H}$ NMR $\delta_{\mathrm{H}}: 6.06\left(\mathrm{~s}, 2 \mathrm{H}, \mathrm{CH}_{2}\right), 6.08\left(\mathrm{~s}, 2 \mathrm{H}, \mathrm{CH}_{2}\right), 6.95$ (d, $\left.J=8 \mathrm{~Hz}, 1 \mathrm{H}, \mathrm{CH}\right), 6.98-7.07$ (m, 2H, Ph-H), 7.08 (d, $J=8 \mathrm{~Hz}, 1 \mathrm{H}, \mathrm{CH}), 7.25$ (d, $J=8 \mathrm{~Hz}, 1 \mathrm{H}, \mathrm{CH}), 7.31$ (d, $J=8 \mathrm{~Hz}, 1 \mathrm{H}$, $\mathrm{CH}$ ), 7.38 (s, 2H, $\mathrm{NH}_{2}$ ), 7.42-7.70 (m, 4H, Ph-H), 7.75 (brs, 1H, NH), 11.67 (s, 1H, NH); ${ }^{13} \mathrm{C}$ NMR $\delta_{\mathrm{C}}$ : 156.4, 149.1, 148.4, 148.3, 148.2, 139.9, 135.4, 131.2, 130.6, 125.2, 123.5, 121.0, 116.2, 108.9, 106.9, 106.3, 101.9, 101.5; HRMS $m / z$ (ESI): calcd for $\mathrm{C}_{20} \mathrm{H}_{19} \mathrm{~N}_{4} \mathrm{O}_{4}$ $[\mathrm{M}+\mathrm{H}]^{+}$379.1406, found 379.1396.

2j: 1,5-Bis(2,4-dichlorophenyl)-1,4-pentadien-3-one amidinohydrazone hydrochloride ${ }^{1} \mathrm{H}$ NMR $\delta_{\mathrm{H}}: 7.17$ (d, $\left.J=16 \mathrm{~Hz}, 1 \mathrm{H}, \mathrm{CH}\right), 7.42$ (d, $\left.J=16 \mathrm{~Hz}, 1 \mathrm{H}, \mathrm{CH}\right), 7.46-7.53$ (m, 4H, PH-h), 7.66 (s, 2H, NH ), 7.75-7.81(m, 2H, PH-h), 7.83 (brs, 1H, NH), 7.87 (d, $J=8 \mathrm{~Hz}$, $1 \mathrm{H}, \mathrm{CH}), 8.29$ (d, $J=8 \mathrm{~Hz}, 1 \mathrm{H}, \mathrm{CH}), 11.97$ (s, $1 \mathrm{H}, \mathrm{NH}) ;{ }^{13} \mathrm{C}$ NMR $\delta_{\mathrm{C}}: 134.6,133.9,133.8$, 133.5, 132.9, 132.5, 129.6, 129.3, 129.2, 128.0, 127.9, 127.9, 121.3. $\mathrm{m} / \mathrm{z}$ (EI): 429.1 $[\mathrm{M}+\mathrm{H}]^{+}$.

2k: 1,5-Bis(3,4-dichlorophenyl)-1,4-pentadien-3-one amidinohydrazone hydrochloride ${ }^{1} \mathrm{H}$ NMR $\delta_{\mathrm{H}}: 7.33$ (d, $\left.J=16 \mathrm{~Hz}, 1 \mathrm{H}, \mathrm{CH}\right), 7.50$ (d, $\left.J=16 \mathrm{~Hz}, 1 \mathrm{H}, \mathrm{CH}\right), 7.57$ (d, $J=16 \mathrm{~Hz}, 1 \mathrm{H}$, $\mathrm{CH}), 7.67-7.70$ (m, 3H, Ph-H), 7.72 (d, $J=16 \mathrm{~Hz}, 1 \mathrm{H}, \mathrm{CH}), 7.88$ (d, $\left.J=8 \mathrm{~Hz}, 2 \mathrm{H}, \mathrm{NH}_{2}\right), 7.92$ (brs, $1 \mathrm{H}, \mathrm{NH}), 8.0-8.2$ (m, 3H, Ph-H), 10.48 (s, $1 \mathrm{H}, \mathrm{NH}) ;{ }^{13} \mathrm{C}$ NMR $\delta_{\mathrm{C}}$ : 137.8, 137.2, 132.3, 132.2, 131.1, 130.2, 129.3, 129.2, 128.4, 127.8, 120.3; $\mathrm{m} / z$ (EI): $429.1[\mathrm{M}+\mathrm{H}]^{+}$.

2l: 1-(4-Chlorophenyl)-5-phenyl-1,4-pentadien-3-one amidinohydrazone hydrochloride ${ }^{1} \mathrm{H}$ NMR $\delta_{\mathrm{H}}: 7.27(\mathrm{~d}, J=16 \mathrm{~Hz}, 1 \mathrm{H}, \mathrm{CH}), 7.33-7.45(\mathrm{~m}, 5 \mathrm{H}, \mathrm{Ph}-\mathrm{H}), 7.48(\mathrm{~d}, J=16 \mathrm{~Hz}, 1 \mathrm{H}$, $\mathrm{CH}), 7.54$ (d, $J=16 \mathrm{~Hz}, 1 \mathrm{H}, \mathrm{CH}), 7.68$ (d, $J=16 \mathrm{~Hz}, 1 \mathrm{H}, \mathrm{CH}), 7.72\left(\mathrm{~d}, J=8 \mathrm{~Hz}, 2 \mathrm{H}, \mathrm{NH}_{2}\right.$ ), 7.81 (brs, $1 \mathrm{H}, \mathrm{NH}), 7.86-7.92(\mathrm{~m}, 4 \mathrm{H}, \mathrm{Ph}-\mathrm{H}), 11.95$ (s, $1 \mathrm{H}, \mathrm{NH}) .{ }^{13} \mathrm{C}$ NMR $\delta_{\mathrm{C}}$ : $156.3,139.2$, 136.8, 136.4, 135.7, 135.4, 134.5, 133.5, 130.5, 130.1, 129.5, 129.2, 128.5, 127.7, 119.0, 118.0; HRMS $m / z$ (ESI): calcd for $\mathrm{C}_{18} \mathrm{H}_{18} \mathrm{ClN}_{4}[\mathrm{M}+\mathrm{H}]^{+} 325.1214$, found 325.1217. 


\section{Results and Discussion}

To examine the effect of reaction conditions on the synthesis of title compounds, the condensation of 1,5-diphenyl-1,4-pentadien-3-one (1a) and aminoguanidine hydrochloride was selected as the model under ultrasound irradiation. The results are summarized in Table 1.

As shown in Table 1, the reaction temperature had a significant effect on the condensation. While the reaction was carried out at $15^{\circ} \mathrm{C}, 25^{\circ} \mathrm{C}$, and $35^{\circ} \mathrm{C}$, the yield was 74\%, 85\%, and 94\%, respectively, (Entries 1, 2 and 3). The yield was increased with increasing temperature and reached the maximum at $35^{\circ} \mathrm{C}$. But when the temperature was raised to $45^{\circ} \mathrm{C}$, the yield was dropped to $83 \%$ (Entry 4) and we choose $35^{\circ} \mathrm{C}$ as the appropriate temperature.

The influence of the molar ratio of 1,5-diphenyl-1,4-pentadien-3-one to aminoguanidine hydrochloride on the reaction was observed. When the molar ratio was 1:1, 2a was obtained in $80 \%$ yield (Entry 5). While the molar ratio was increased to 1:1.1 and 1:1.2, the yield was also increased to $83 \%$ and $85 \%$ respectively, but the improvement was not obviously (Entries 4 and 6). In the absence of hydrochloric acid, we also did the experiment for the reaction of 1a with aminoguanidine hydrochloride, the reaction was not taken place at all (Entry 7). It seems that hydrochloric acid plays an important catalytic role in the reaction.

Table 1. The effect of reaction conditions on the yield of $\mathbf{2 a}$ under ultrasound irradiation.

\begin{tabular}{|c|c|c|c|c|c|}
\hline Entry & $\begin{array}{l}\text { Substrate } \mathrm{a} / \text { regent }^{\mathrm{b}} \\
\text { (molar ratio) }\end{array}$ & $\begin{array}{c}\mathrm{HCl} \text { (aq. } \\
36.5 \%), \mathrm{mL}\end{array}$ & Time, h & Temp., ${ }^{\circ} \mathrm{C}$ & $\begin{array}{c}\text { Isolated yield, } \\
\%\end{array}$ \\
\hline 1 & $1: 1.1$ & 0.05 & 2 & 15 & 74 \\
\hline 2 & 1:1.1 & 0.05 & 1.5 & 25 & 85 \\
\hline 3 & 1:1.1 & 0.05 & 1.5 & 35 & 94 \\
\hline 4 & 1:1.1 & 0.05 & 1.5 & 45 & 83 \\
\hline 5 & $1: 1$ & 0.05 & 1.5 & 45 & 80 \\
\hline 6 & $1: 1.2$ & 0.05 & 1.5 & 45 & 85 \\
\hline 7 & $1: 1.1$ & - & 1.5 & 45 & NR \\
\hline
\end{tabular}

${ }^{a}$ 1,5-Diphenyl-1,4-pentadine-3-one. ${ }^{b}$ Aminoguanidine hydrochloride.

From the above results, a typical experimental procedure was chosen as follows: the molar ratio of substrate to aminoguanidine hydrochloride (1:1.1), hydrochloric acid $(0.05 \mathrm{~mL}), \mathrm{EtOH}$ $(10 \mathrm{~mL})$, reaction temperature $\left(35-37^{\circ} \mathrm{C}\right)$. Using this reaction system, a series of experiments for the synthesis of 1,5-diaryl-1,4-pentadien-3-one amidinohydrazone hydrochloride were performed under ultrasound irradiation. The results were summarized in Table 2.

As shown in Table 2, the condensation of 1,5-diaryl-1,4-pentadien-3-one and aminoguanidine hydrochloride was carried out in good to excellent yield catalyzed by hydrochloric acid at $35-37^{\circ} \mathrm{C}$ under ultrasound irradiation.

In order to verify the effect of ultrasound irradiation, the model reaction was also performed by stirring alone under silent condition at the refluxing temperature for $4 \mathrm{~h}$, the yield of 2a was $60 \%$ (Entry a). While under ultrasound the reaction can be completed in $94 \%$ yield at $35^{\circ} \mathrm{C}$ within $1.5 \mathrm{~h}$. At the same temperature $\left(35-37^{\circ} \mathrm{C}\right)$ and time $(1.5 \mathrm{~h})$ by stirring, the yields (2i-l) were much lower than that under ultrasound irradiation. For example, the condensation of $\mathbf{1} \mathbf{k}$ with amidinohydrazone hydrochloride was stirred to offer $\mathbf{2 k}$ in $37 \%$ yield, whereas under ultrasound $\mathbf{2 k}$ was obtained in $90 \%$ yield (Entry $\mathbf{k}$ ). It's clear that ultrasound can accelerate the reaction and improve the result. 
Table 2. The synthesis of 2a-l with or without ultrasound irradiation.

\begin{tabular}{|c|c|c|c|c|c|c|c|c|}
\hline \multirow{2}{*}{ 密 } & \multirow{2}{*}{$\begin{array}{l}\mathrm{R}_{1} \\
\mathrm{H}\end{array}$} & \multirow{2}{*}{$\begin{array}{l}\mathrm{R}_{2} \\
\mathrm{H}\end{array}$} & \multirow{2}{*}{ 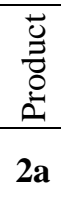 } & \multicolumn{2}{|c|}{$\begin{array}{c}\text { Ultrasound }^{\mathrm{C}} \\
\text { Time, h } \\
\text { Yield, \% } \\
\end{array}$} & \multicolumn{2}{|c|}{$\begin{array}{c}\text { Stir. }^{\mathrm{d}} \text { (Lit.) }^{8} \\
\text { Time, h } \\
\text { Yield, \% }\end{array}$} & \multirow{2}{*}{$\begin{array}{c}\text { m.p., }{ }^{\circ} \mathrm{C} \\
\text { (Lit.) } \\
223-224 \\
(223-225)\end{array}$} \\
\hline & & & & 1.5 & 94 & $4(16)$ & $\begin{array}{l}60^{\mathrm{a}} \\
(69)\end{array}$ & \\
\hline b & 2-Cl & $2-\mathrm{Cl}$ & $2 b$ & 1.5 & 88 & $\begin{array}{c}1.5 \\
(6.5)\end{array}$ & $\begin{array}{l}65^{\mathrm{a}} \\
(70)\end{array}$ & $\begin{array}{c}243-244 \\
(243-244)\end{array}$ \\
\hline C & $3-\mathrm{Cl}$ & $3-\mathrm{Cl}$ & $2 c$ & 1.5 & 86 & $\begin{array}{l}1.5 \\
(7)\end{array}$ & $\begin{array}{l}84^{a} \\
(40)\end{array}$ & $\begin{array}{c}217-219 \\
(217-220)\end{array}$ \\
\hline d & $4-\mathrm{Cl}$ & $4-\mathrm{Cl}$ & 2d & 1.5 & 90 & $4(4)$ & $\begin{array}{l}88^{a} \\
(58)\end{array}$ & $\begin{array}{c}233-234 \\
(233-234)\end{array}$ \\
\hline e & $4-\mathrm{CH}_{3}$ & $4-\mathrm{CH}_{3}$ & $2 e$ & 1.5 & 89 & 1.5 & $85^{\mathrm{a}}$ & $\begin{array}{c}179-180 \\
(179.5-180.5)\end{array}$ \\
\hline$f$ & $\mathrm{H}$ & $4-\mathrm{CH}_{3}$ & $2 f$ & 1.5 & 88 & 1.5 & $86^{\mathrm{a}}$ & $183-184$ \\
\hline g & $\mathrm{H}$ & $4-\mathrm{OCH}_{3}$ & $2 g$ & 1.5 & 90 & 1.5 & $83^{\mathrm{a}}$ & $146-148$ \\
\hline $\mathrm{h}$ & $4-\mathrm{OCH}_{3}$ & $4-\mathrm{OCH}_{3}$ & $2 \mathrm{~h}$ & 1.5 & 85 & 4 & $86^{\mathrm{a}}$ & $208-209$ \\
\hline $\mathrm{i}$ & $3,4-\left(\mathrm{OCH}_{2} \mathrm{O}\right)-$ & $3,4-\left(\mathrm{OCH}_{2} \mathrm{O}\right)-$ & $2 \mathbf{i}$ & 1.5 & 86 & 1.5 & $53^{\mathrm{b}}$ & $234-235$ \\
\hline j & $2,4-\mathrm{Cl}_{2}$ & $2,4-\mathrm{Cl}_{2}$ & $2 \mathbf{j}$ & 1.5 & 80 & 1.5 & $56^{\mathrm{b}}$ & $187-188$ \\
\hline $\mathrm{k}$ & $3,4-\mathrm{Cl}_{2}$ & $3,4-\mathrm{Cl}_{2}$ & $2 \mathbf{k}$ & 1.5 & 90 & 1.5 & $37^{\mathrm{b}}$ & $237-239$ \\
\hline 1 & $\mathrm{H}$ & $4-\mathrm{Cl}$ & 21 & 1.5 & 85 & 1.5 & $68^{\mathrm{b}}$ & $209-210$ \\
\hline
\end{tabular}

${ }^{a}$ Refluxing temperature. ${ }^{b} 35-37{ }^{\circ} \mathrm{C} .{ }^{c}$ Bath temperature $35-37{ }^{\circ} \mathrm{C}$. ${ }^{d}$ Stirring alone without ultrasound.

Cavitation is the origin of sonochemistry. Liquids irradiated with ultrasound can produce bubbles. Under the proper conditions these bubbles undergo a violent collapse, which generates localized "hot spot" with a transient high temperature and pressures, inducing highly reactive species are locally produced, which are responsible for the chemical effects of ultrasound on homogeneous solutions. In the some case, sonication can probably provide more efficient stirring ${ }^{12,13}$. These can cause the reaction to take place rapidly.

From the data listed in Table 2, we can see that the dramatic improvements were the short reaction time and high yield. According to the method catalyzed by $\mathrm{HCl}$ in the literature $^{8}$, the refluxing time, and the yield of $\mathbf{2 a}$ were $16 \mathrm{~h}$ and $69 \%$, respectively, for the reaction of 1a and aminoguanidine hydrochloride. The present procedure gave $94 \%$ yield at $35-37^{\circ} \mathrm{C}$ within $1.5 \mathrm{~h}$ (Entry a). The refluxing time and yield of 2c were $7 \mathrm{~h}$ and $40 \%$, respectively, for the condensation of $\mathbf{1 c}$ and aminoguanidine hydrochloride, whereas under ultrasound 2c was afforded in $86 \%$ yield at $35-37^{\circ} \mathrm{C}$ within $1.5 \mathrm{~h}$ (Entry c).

In these experiments, bischalcones, carrying either electron-donating or electronwithdrawing substituents reacted very well and the condensation of $\mathbf{2 a}$ was easier than that of other bischalcones, it may be that the steric hindrance around the carbonyl group inhibited the attack of aminoguanidine hydrochloride to carbonyl group.

From the above results, we can deduce that the yields are higher than those described in literatures. Compared with the reported, the main advantages of the method are milder conditions, higher yields, especially, a much shorter reaction time.

\section{Conclusion}

An efficient and convenient procedure for the synthesis of some 1,5-diaryl-1,4-pentadien-3one amidinohydrazone hydrochloride has been developed under ultrasound irradiation. Compared with the reported method, this procedure provided several advantages such as milder reaction condition, shorter reaction time and higher yield. 


\section{References}

1. LaFrate A L, Gunther J R, Carlson K E, and Katzenellenbogen J A, Bioorg Med Chem., 2008, 16, 10075-10084.

2. Sielaff F, Than M E, Bevec D, Lindberg I, and Steinmetzer T, Bioorg Med Chem., Lett., 2011, 21, 836-840.

3. Wright Jr W B and Tomcufcik A S, United States Patent, 1981 4, $289,769$.

4. Brown D G, United States Patent, 1982, 4, 349, 553.

5. $\quad$ Stegelmeier H, Morich F J and Knorr A, Eur Paent., 1985, 0163888.

6. Takai A and Saikawa I, J Pharm Soc Jap., 1964, 84, 1-9.

7. Takai A and Saikawa I, J Pharm Soc Jap., 1964, 84, 16-23.

8. Tomcufcik A S, United States Patent, 1975, 3, 878,201.

9. Lovell J B, United States Patent, 1978, 3, 087,525.

10. Mason T J and Peters D, Practical Sonochemistry, 2ed, Ellis Horwood, New York, 2002.

11. Li J T, Wang S X, Chen G F, and Li T S, Curr Org Synth., 2005, 2, 415-436.

12. Mason T J, Practical Sonochemistry, Ellis Horwood, New York, 1991.

13. Dahlem O, Reisse J, and Halloin V, Chem Eng Sci., 1999, 54, 2829-2838.

14. Chen G F, Li J T, Duan H Y, and Li T S, Chem J Int., 2004, 6, 7-10.

15. Kimura T, Sakamoto T, Leveque J M, Sohmiya H, Fujita M, Ikeda S, and Ando T, Ultrason Sonochem., 1996, 3, 157-161. 


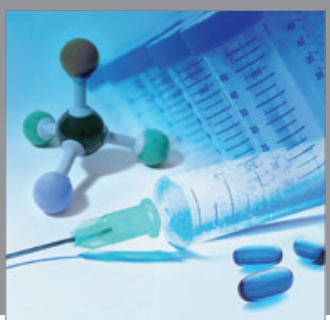

International Journal of

Medicinal Chemistry

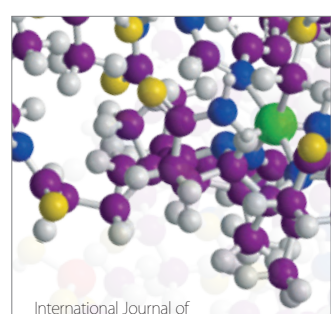

Carbohydrate Chemistry

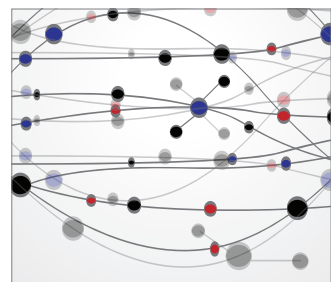

The Scientific World Journal
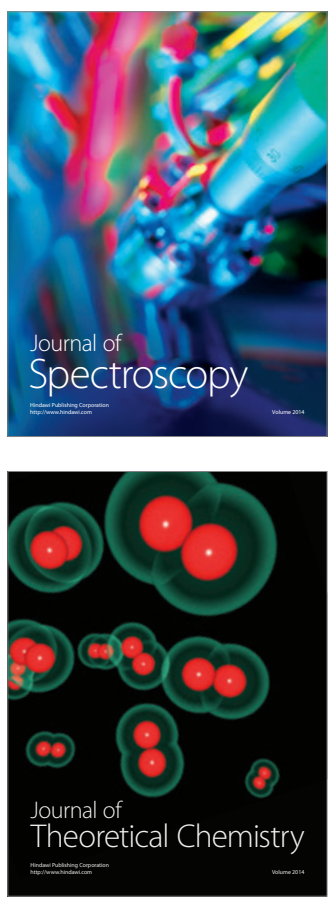
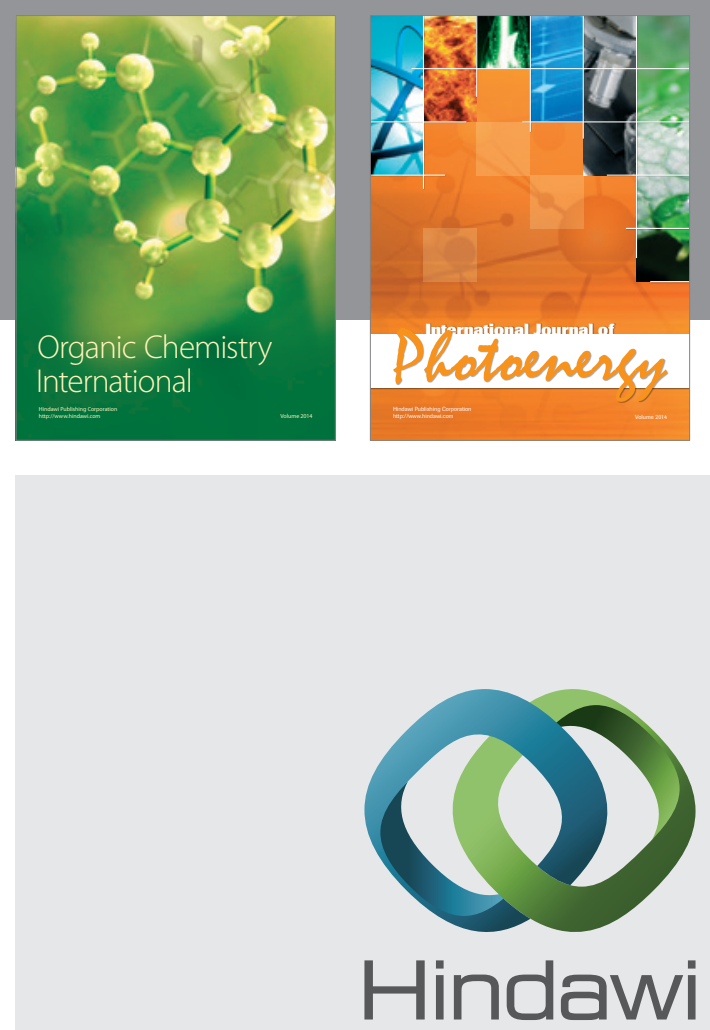

Submit your manuscripts at

http://www.hindawi.com
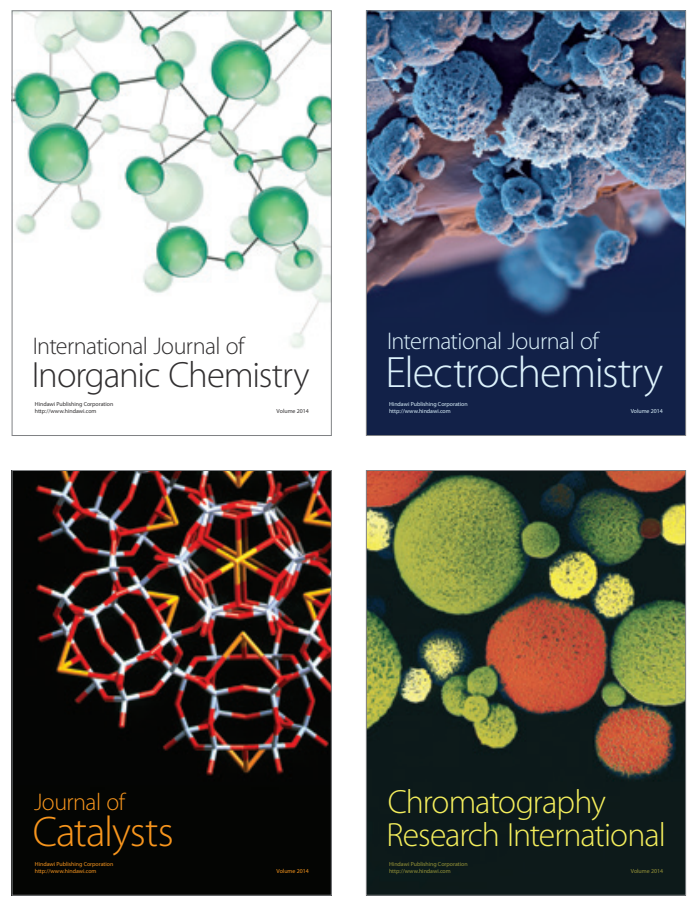
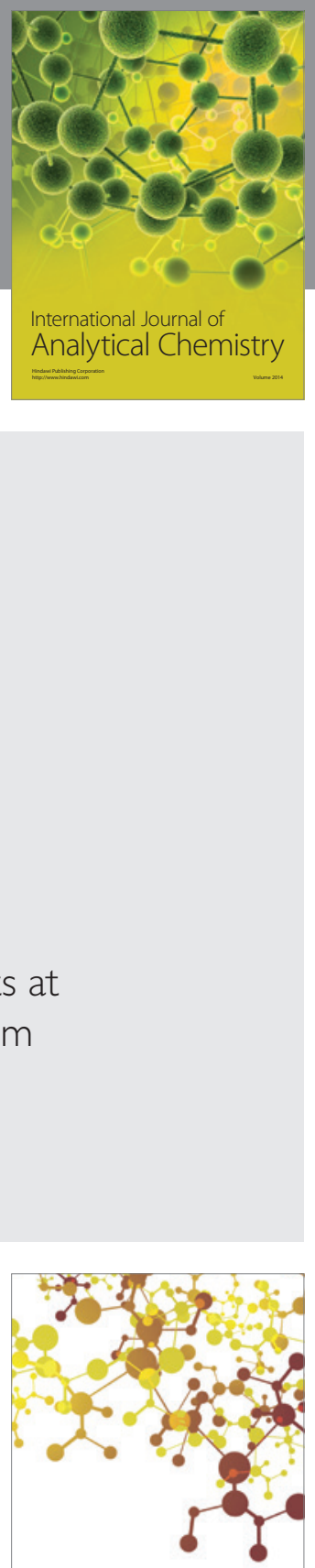

Journal of

Applied Chemistry
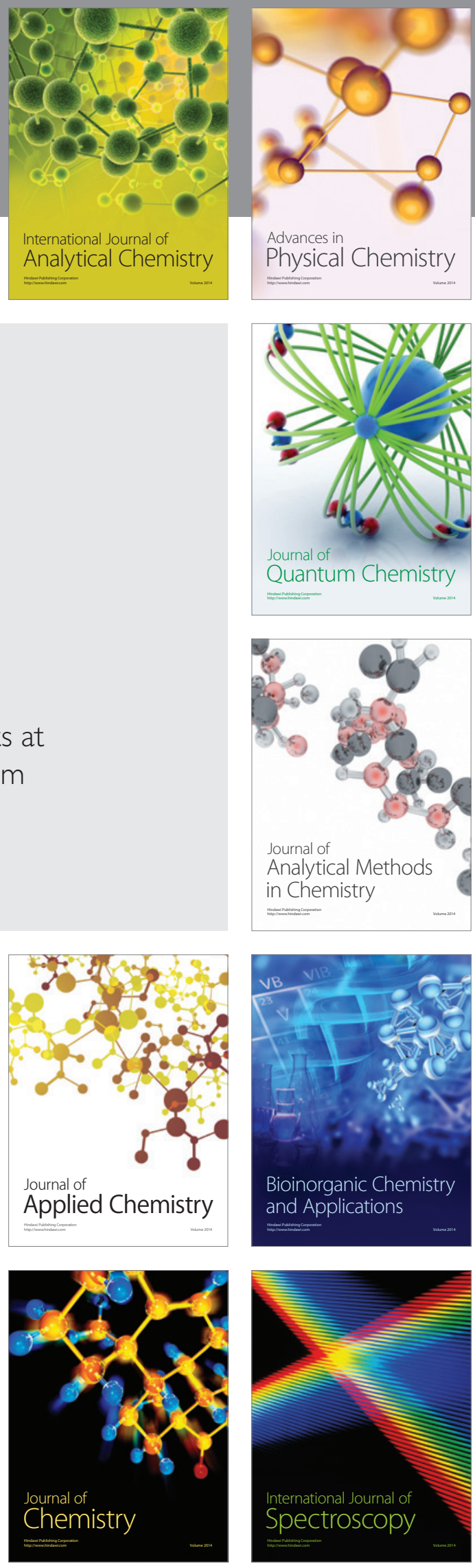